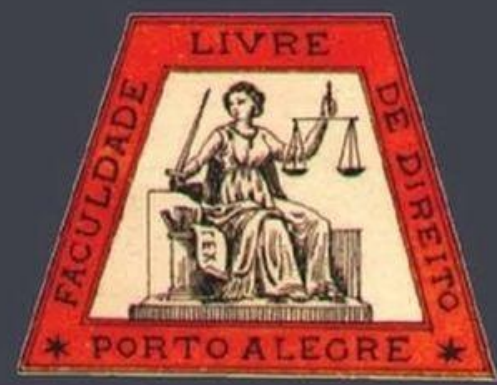

\title{
O modelo de tribunal multiportas americano e o sistema brasileiro de solução de conflitos
}

The American multi-door courthouse concept and the Brazilian conflict settlement system

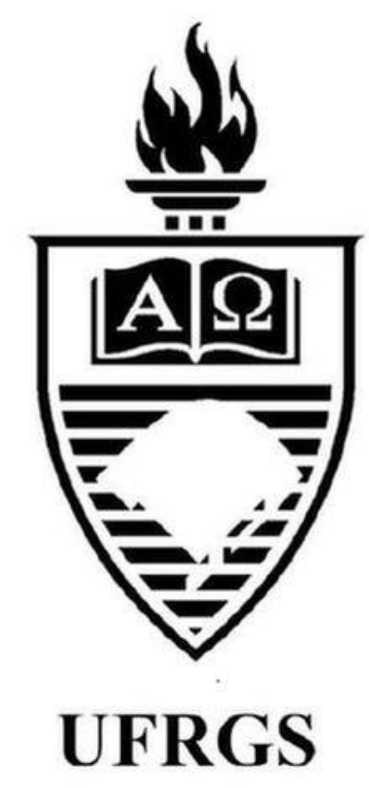

Tânia Lobo Muniz

Pontifícia Universidade Católica de São Paulo

Isabel Cristina de Moura

Universidade Estadual de Londrina 


\title{
O modelo de tribunal multiportas americano e o sistema brasileiro de solução de conflitos
}

\author{
The American multi-door courthouse concept and the Brazilian conflict settlement system
}

Tânia Lobo Muniz*

Marcos Claro da Silva**

\section{REFERÊNCIA}

MUNIZ, Tânia Lobo; SILVA, Marcos Claro da. O Modelo de Tribunal Multiportas Americano e o Sistema Brasileiro de Solução de Conflitos. Revista da Faculdade de Direito da UFRGS, Porto Alegre, n. 39, vol. esp., p. 288-311, dez. 2018.

\section{RESUMO}

O artigo faz uma análise do sistema de solução de conflitos brasileiro, a partir dos pressupostos de estabelecimento do sistema multiportas de solução de conflitos norteamericano, representado principalmente pelo conceito de Tribunal Multiportas, a partir da realidade mundial na difusão dos métodos alternativos. Parte do exame dos meios alternativos de solução de conflitos dentro dessa perspectiva de profusão em todo o mundo, para depois delimitar como são tratados no Brasil. Após, apresenta o conceito de Tribunal Multiportas concebido nos Estados Unidos e sua aplicação concreta em alguns estados americanos. Ao final, sob os premissas delineadas, estabelece o grau de implantação do conceito de Tribunal Multiportas no Brasil, da forma como estabelecido nos Estados Unidos, apontando o grau de estabelecimento de um sistema judiciário multiportas.

\section{PALAVRAS-CHAVE}

Conflitos de Interesse. Tribunal Multiportas. Acesso à Justiça. Meios Alternativos.

\begin{abstract}
This paper analyzes the Brazilian conflict settlement system, based on the assumptions of the establishment of the American multi-door conflict resolution system, represented mainly by the concept of multi-door courthouse, based on the diffusion of alternative methods on the world. It begins with an examination of the alternative methods of conflict resolution in the perspective of its profusion around the world and then delineate how they are treated in Brazil. After, it presents the concept of multi-door courthouse designed in the United States and its daily use in some American states. In the end, in the light of the delimited premises, establishes the degree of implementation of the concept of multi-door courthouse in Brazil, as it's established in the United States, pointing the degree of establishment of a multi-door judicial system.
\end{abstract}

\section{KEYWORDS}

Disputes. Multi-door Courthouse. Justice Access. Alternative Dispute Resolution.

\section{SUMÁRIO}

Introdução. 1. Os meios alternativos de solução de conflitos. 2. O Tribunal multiportas: experiência americana. 3. Sobre a instituição de tribunais multiportas no Brasil. Conclusão. Referências.

\section{INTRODUÇÃO}

As relações humanas têm sido, cada vez mais, intensas. Esse movimento é decorrência lógica dos processos inerentes à globalização, das transformações tecnológicas, capazes de levar informações ao outro lado do mundo em instantes, ascensão dos direitos sociais, de matéria consumerista, trabalhistas, além da evolução dos meios de transporte, cada vez mais seguros e rápidos, encurtando as distâncias terrestres e tornando as pessoas mais próximas. Novas relações jurídicas, novos conflitos.

\footnotetext{
* Doutorado em Direito pela Pontifícia Universidade Católica de São Paulo (2004).

*** Mestre em Direito pela Universidade Estadual de Londrina.
} 
A evolução evidenciada trouxe, por conta dessa nova dinâmica, importantes reflexos jurídicos, com o aperfeiçoamento e desenvolvimento, cada vez mais latente, do Direito em todo o mundo, tanto de ordem pública quanto de ordem privada, para disciplinar estes novos conflitos, em questões relativas aos diferentes objetos e áreas da vida humana, desde relações de consumo até as discussões trabalhistas.

Nesse ambiente, o fomento da solução pacífica de controvérsias se evidencia nas mais diversas relações, tanto em âmbito público quanto no privado. E, como não poderia deixar de ocorrer, essa construção se reflete na necessária imbricação entre essa nova realidade e o sistema de justiça, para que estas controvérsias tenham adequado tratamento pelo Estado e não fiquem à margem de solução.

$\mathrm{O}$ processo judicial comum, dito adversarial, não pode andar sozinho nessa caminhada, pois não possui capacidade de lidar com toda essa gama de novos direitos, surgindo assim, a tendência à utilização dos meios alternativos de solução de conflitos, renovado pelos estudos em Alternative Dispute Resolution, concebidos, inicialmente, nos Estados Unidos.

Essa predisposição aos meios alternativos promoveu à profusão desses institutos no âmbito interno dos Estados, utilizados inclusive para abrandar a crise de acesso à justiça, evidenciada por Bryan Garth e Mauro Capelletti ao identificarem as ondas reformatórias da justiça, voltadas à superação dos obstáculos evidenciados ao alcance daquela, apontando a terceira onda para a necessidade de incentivar os meios

\footnotetext{
${ }^{1}$ GARTH, Bryan, CAPELLETTI, Mauro. Acesso à Justiça. Porto Alegre: Sergio Antonio Fabris Editor. 2002, p. 39.

${ }^{2} \mathrm{O}$ conceito foi apresentado na palestra de abertura da Pound Conference, em 1976, em Saint Paul, Minessotta, conforme explica Frank Sander em: Diálogos entre os
}

alternativos de solução de conflitos. Assim é que os Estados Unidos da América passaram a viver essa reforma, como dito acima, a partir da década de setenta, do século XX, com a utilização destes mecanismos alternativos de acesso à justiça ${ }^{1}$.

Dentro desse contexto, Frank Sander, professor da Harvard Law School, concebeu um conceito inovador denominado Tribunal Multiportas, pelo qual num único centro de justiça devem estar à disposição das partes a triagem do conflito que será levado à discussão, para que se defina qual método será o adequado para alcançar resultados mais satisfatório, assim como instrumentos para a utilização dos mesmos ${ }^{2}$.

No Brasil, a adoção de métodos autocompositivos para a solução de controvérsias teve e tem grande influência das experiências estrangeiras, com a internalização de modelos utilizados em outros ordenamentos. Contudo, essa introdução demanda uma análise que possibilite entender as nuances e delineamentos do sistema localmente adotado.

Com esse objetivo, a pesquisa contextualiza a necessidade de que o sistema de justiça se adéque às transformações ocorridas no mundo e aos métodos disponíveis à solução de eventuais conflitos que surjam dessas novas relações, para apontar a tendência que influenciou a criação do conceito de Tribunal Multiportas, além de examiná-lo a partir do modelo concebido e aplicado nos Estados Unidos da América, a fim de avaliar se as premissas básicas se verificam no âmbito nacional.

Espera-se, como resultado, definir se está ou não estabelecido o conceito de Tribunal Multiportas no Brasil, seu grau de implantação

professores Frank Sander e Mariana Hernandez Crespo: explorando a evolução do Tribunal Multiportas, in Investindo no capital social para maximizar o sistema de solução de conflitos no Brasil. (Org.) CRESPO, Maria Hernandez. Rio de Janeiro: FGV Editora, 2012, p. 31. 
por aqui, além da constatação dos aspectos necessários à evolução dessa ideia, a partir da experiência norte-americana no desenvolvimento de tribunais com essas características, para que seja possível chegar a uma noção de sistema multiportas de solução de conflitos.

A pesquisa parte de constatações genéricas para as específicas que serão objeto da conclusão a que se pretende chegar, utilizando-se, para tanto, do método hipotético-dedutivo, além do indutivo. Serão importantes também dados empíricos mostrados em pesquisas nos Estados Unidos e no Brasil, para subsidiar adequadamente a análise ora proposta.

\section{OS MEIOS ALTERNATIVOS DE SOLUÇÃO DE CONFLITOS}

A vida contemporânea é internacionalizada e socializada em diversos aspectos, o que também ocorre com todas as atividades humanas, situação que leva a uma série de fenômenos de natureza jurídica, que devem ser enfrentados pelos Estados isoladamente, mas também pelas entidades regionais e internacionais no plano coletivo ${ }^{3}$, porquanto este novo panorama pode levar aos mais variados conflitos de interesses.

Ainda, levando em conta o aspecto que se refere à globalização, é possível ver um fluxo contínuo de pessoas de todas as nacionalidades que aqui chegam e estabelecem relações privadas, bem como, por outro lado, um elevado número de brasileiros que rumam às diferentes localidades do mundo para fazer turismo, entabular negócios, estudar, se submeter a tratamentos médicos, ou até mesmo para residir nesses locais ${ }^{4}$.

\footnotetext{
3 DOLINGER, Jacob, TIBURCIO, Carmen. Direito Internacional Privado: Parte Geral e Processo Internacional. Rio de Janeiro: Forense. 2016, p. 1.

${ }^{4}$ BASSO, Maristela. op. Cit. p. 4.

${ }^{5} \mathrm{O}$ atual relatório Justiça em números, elaborado pelo

Conselho Nacional de Justiça, aponta que a taxa de
}

Evidentemente que dessas recentes relações surgiram e ainda surgem conflitos entre aqueles que as constituem, sendo necessário que se estabeleça, tanto em plano interno quanto no plano externo, métodos que tenham como finalidade solucionar estas controvérsias, principalmente por conta das tendências e perspectivas mencionadas acima, dada a ineficiência da função judiciária para solucionar essa massa de novas demandas ${ }^{5}$.

Foi a partir desse novo panorama que surgiram, nos Estados Unidos, as ADRs (Alternative Dispute Resolution), expressão cunhada para designar todo e qualquer procedimento destinado à solução de controvérsias que seja alheio à intervenção de uma autoridade judicial. Se constituem em vários métodos de liquidação de desajustes que levam em consideração os objetivos de cada um, as possibilidades disponíveis além da maneira como os sujeitos relacionam seus objetivos com as alternativas delineadas ${ }^{6}$.

Desde o momento em que as ADRs passaram a ter maior atenção pela cultura jurídica de muitos países, suas práticas levaram a bons resultados quando foram efetivamente implantadas. Na Inglaterra, por exemplo, o aumento da utilização da mediação, da conciliação e da arbitragem, com a consolidação da cultura de acordos, tornou a instância pública para julgamentos a última via a ser procurada ${ }^{7}$.

Os principais métodos para a solução de conflitos são a arbitragem, a mediação, a conciliação, além, é claro, o processo contencioso comum. Os três primeiros são chamados de alternativos por conta de sua inovação na ciência

congestionamento da Justiça Estadual ainda se encontra no elevado patamar de $75 \%$ (setenta e cinco por cento). Justiça em Números 2017: ano-base 2016/Conselho Nacional de Justiça - Brasília: CNJ, 2017.

${ }^{6}$ Ibidem, Loc. Cit.

${ }^{7}$ ANDREWS, Neil. op. cit., p. 31. 
processual tradicional, rompendo com a centralização do foro judicial, e seu principal instrumento, como única órbita disponível para discussão de questões jurídicas.

Outros métodos, contudo, são mencionados e têm larga utilização no exterior, principalmente nos Estados Unidos ${ }^{8}$. Entre todos, sem olvidar da existência de outros ${ }^{9}$, cite-se, por possuírem maior relevância, a negociação, a avaliação de terceiro neutro e o mini-trial ${ }^{10}$.

Dentro dessa nova realidade é que a arbitragem ressurge como alternativa. Quando se fala em negócios jurídicos privados assinados internacionalmente, a celebração destes pactos envolve, na maioria dos casos, cláusulas compromissórias arbitrais, o que torna a disputa, inclusive, mais justa, pois não a submete à jurisdição de algum dos Estados das partes que contrataram. Duas razões são apontadas como principais para a utilização da arbitragem: a redução dos custos à solução de conflitos e o estabelecimento de um sistema de incentivos ao cumprimento dos contratos ${ }^{11}$.

A arbitragem é o meio alternativo de solução de litígios, pelo qual é indicado um terceiro imparcial pelas próprias partes ou pelo órgão ao qual estejam elas vinculadas, para que possa apresentar solução à questão que lhe é entregue, sob o comprometimento das partes em respeitar aquilo que for decidido pelo juízo $\operatorname{arbitral}^{12}$.

\footnotetext{
${ }^{8}$ Cf. ASPERTI. op. cit., p. 119.

${ }^{9}$ Sobre alguns meios alternativos de solução de conflitos sem grande relevância nos Estados Unidos em pesquisa realizada in loco, no Estado de Connecticut, Maria Cecilia de Araújo Asperti (2011, p. 118-119), observou que: "No estado de Connecticut, o objetivo do ADR office também é o oferecimento de outros mecanismos para a resolução de disputas que não o julgamento judicial. Além dos métodos de resolução de conflitos mais usuais, como a mediação e a arbitragem, o ADR Office trabalha com variações de processos de viés mais avaliativo, como o early neutral evaluation, o summary jury trial e o attorney trial referee. Com exceção deste último, os demais mecanismos avaliativos foram mal avaliados pela comissão designada
}

Existem, quanto à arbitragem, dois momentos nos quais podem as partes convencionar resolver suas disputas por meio deste método alternativo: aquele acordo celebrado antes do conflito, instrumentado pela cláusula compromissória, denominado arbitragem ex ante facto, assim como o convencionado após o surgimento da disputa, viabilizado pelo compromisso arbitral, chamado de arbitragem ex post facto, ensejando, as duas modalidades, a atuação de um árbitro que, na qualidade de terceiro imparcial, proferirá sentença arbitral para solucionar o conflito pela forma eleita ${ }^{13}$.

Não são todos os conflitos que podem ser arbitrados, tendo em vista o aspecto negocial que envolve os processos arbitrais, o qual impõe limites para que as partes celebrem a convenção arbitral e, dessa constatação, surge a ideia de arbitramento dos conflitos, levando em conta um viés subjetivo, relacionado àqueles que podem convencionar sobre arbitragem, e outro objetivo, que diz respeito à matéria que pode ser $\operatorname{arbitrada}^{14}$.

Este aspecto se relaciona com as teorias sobre a natureza jurídica da arbitragem, destacando-se quatro delas, na tentativa de explicar o instrumento. Há os que entendem a arbitragem como exercício legítimo da jurisdição, tendo o árbitro um papel "quase judicial”. Ainda, neste contexto, estão os que a entendem como uma entidade autônoma, desligada do direito

para elaboração do relatório de recomendações ao ADR Office, que constatou que que demandavam um dispêndio de recursos tempo dos envolvidos (juízes, funcionários e jurados), quase equivalente ao processo judicial, sem a produção de um resultado definitivo e vinculante.

${ }^{10}$ AZEVEDO. op. cit., p; 32.

11 SALAMA, Bruno. A Economia da Arbitragem. In: Manual de Direito e Economia no Brasil, Luciano B. Timm (org.). São Paulo: Atlas, 2012, p. 03.

12 MORAES, Márcio André Medeiros. Arbitragem nas relações de consumo. $1^{\text {a }}$ Ed. Curitiba: Juruá, 2005, p. 92.

${ }^{13}$ SALAMA, Op. Cit., p. 6.

${ }^{14}$ AZEVEDO, Op. Cit., p. 35. 
positivo. Existem também aqueles que consideram a natureza contratual da arbitragem para definir sua natureza. Por fim, a teoria mista procura explicar a arbitragem a partir desse viés contratual, mas sem desconsiderar o aspecto público que envolve este meio alternativo ${ }^{15}$.

No Brasil existem condições para contratar, que devem obedecer às regras gerais de capacidade previstas no Código Civil, ficando os incapazes impossibilitados de instaurar essa esfera decisória. Além disso, é preciso que os direitos a serem discutidos por meio da arbitragem sejam de natureza patrimonial e disponível, entendidos esses como aqueles que permitem a livre disposição pelas partes, sem qualquer tipo de norma cogente a exigir a interferência estatal para tanto ${ }^{16}$.

Em geral são apontados como benefícios da arbitragem a celeridade com que se alcança a sentença arbitral, a informalidade do procedimento, a confiabilidade nos árbitros, a especialidade que envolve as decisões que tendem à complexidade, a economicidade do processo em relação ao comum estatal, além do sigilo do seu desenrolar, o que pode ser muito útil às transações negociais ${ }^{17}$.

Esse movimento mundial que leva à utilização da arbitragem deságua na utilização de outros métodos destinados à solução de conflitos de interesse, tendo, de igual forma, um terceiro imparcial auxiliando as partes na busca pelas soluções, mas sem interferir como na arbitragem, na medida em que nestes métodos não irá ele decidir efetivamente a lide objeto, atuando de forma mais neutra, como ocorre na mediação e na conciliação.

\footnotetext{
${ }^{15}$ WAMBIER, Teresa Arruda Alvim. A Discussão sobre a disponibilidade do controle judicial da sentença arbitral e seus limites in Revista Brasileira de Arbitragem, no 50, AbrJun, 2016, p. 09-10.

${ }^{16}$ CARMONA, Op. Cit., p. 55-56.

17 RIBEIRO, Gustavo Pereira Leite. Arbitragem nas relações de Consumo. $1^{\text {a }}$ Ed. Curitiba: Juruá. 2006, p. 189.
}

O processo de mediação é utilizado para a solução de disputas que compreendam relações de trato continuado, as quais existem no tempo antes do surgimento do conflito e têm que se protrair após o seu desaparecimento. O conflito é, assim, reconstruído a partir das angustias das partes, que são colocadas em debate e mediadas, a fim de facilitar o diálogo e sedimentar, dessa forma, a solução da controvérsia.

É possível enxergar a técnica da mediação a partir de diferentes maneiras, muito por conta do conflito - aspecto da natureza humana multifacetado, o que se converte na construção de modelos distintos. É importante, por isso, abordar, ainda que brevemente, as escolas de mediação, que têm premissas teóricas e práticas muito peculiares.

A primeira delas é a escola da negociação assistida baseada em princípios (problem solving), desenvolvida no programa de negociação de Harvard, e considera a mediação a partir de dois tipos de abordagens: a adversarial e a de solução de problemas, sendo que a primeira é focalizada em um recurso limitado (como o dinheiro) e que as partes devem decidir se vão dividi-lo e como o farão; já a segunda, de outro lado, tem por finalidade revelar e compor os interesses subjacentes das partes ${ }^{18}$.

A segunda é a escola da mediação transformativa, e segundo os seus preceitos os conflitos não devem ser enxergados como problema, mas, de outra forma, como uma chance construir oportunidades de transformação das próprias partes, sob dois pontos de vista: autoconhecimento, bem como conhecimento do lado adverso e, por isso, é que se estabelece que a

${ }^{18}$ GABBAY, Daniela Monteiro. Mediação \& Judiciário: Condições necessárias para a institucionalização dos meios autocompositivos de solução de conflitos. 2011. 274 f. Tese (Doutorado em Direito) - Faculdade de Direito da Universidade de São Paulo, p. 52. 
mediação transformativa tem foco mais no processo do que no resultado ${ }^{19}$.

Já a terceira é a escola da mediação circular narrativa e, da mesma forma que a escola da mediação transformativa, é baseada na relação e não no resultado. Parte-se do reconhecimento da importância da arte de conversar como a forma mais transcendental de aprendizado humano, e essa troca entre os seres humanos permite que se aprenda cada vez mais, e a mediação é concebida como um processo conversacional, que se dá na comunicação ${ }^{20}$.

Nesse contexto o grande mérito da mediação consiste no seu objetivo principal, de preservar as relações existentes entre os personagens do conflito, os quais, ao chegar ao consenso, terão maiores condições de continuar convivendo de maneira amistosa, civilizada e produtiva a partir daquele instante ${ }^{21}$. Esse fator revela um apelo sociológico muito grande a favor da mediação, principalmente em relações familiares.

Por outro lado, a conciliação é um processo diferente da mediação, em que pese a frequente confusão com que tratadas no meio jurídico, residindo a oposição entre ambas na postura tomada pelo intermediador do conflito, um tanto quanto mais ativa na conciliação, pois propõe acordos e os costura, nos termos do que lhe é exposto pelas partes. É, por essa razão, que a conciliação é indicada a casos inerentes às relações esporádicas entre as partes em conflito.

Em linhas gerais, na mediação o mediador age como que um facilitador no processo,

\footnotetext{
${ }^{19}$ GABBAY, Op. Cit., p. 55.

20 VASCONCELOS, Carlos Eduardo. Mediação de Conflitos e Práticas Restaurativas: Modelos, Processos, Ética e Aplicações. São Paulo: Método. 2008, p. 80.

${ }^{21}$ MENDES, Maria Lúcia R. de Castro P. Mediação e Conciliação. Histórico dos métodos adequados de solução de conflitos e experiências contemporâneas no Brasil e em outros países, in Estudos Avançados em Mediação e Arbitragem. São Paulo: Campos Elíseos. 2014, p. 88.
}

negociando a comunicação entre as partes e permitindo que cheguem à uma solução para a contenda por si sós, a partir da identificação dos interesses em jogo e fazendo a flexibilização de ambos os lados; conquanto o conciliador tenha uma função muito parecida com a do mediador, existe uma diferença importante: o conciliador propõe soluções aos casos, enquanto o mediador somente colabora para que as partes se componham amigavelmente ${ }^{22}$.

Por conta de todos esses aspectos, a experiência em outros países ${ }^{23}$ tem mostrado uma busca pelos métodos alternativos de solução de controvérsias cada vez mais acentuada no âmbito interno, mas também nas relações internacionais, entre aquelas empresas que celebram negócios em diferentes partes do globo.

Exemplo disso é a Corte Internacional da Arbitragem da Câmara de Comércio Internacional de Paris (CCI/ICC), junto com o círculo de especialistas que se agregaram ao seu redor a partir de sua criação, sendo que o sistema de solução de conflitos, baseado nos meios alternativos, adotado por essa câmara é fundamentado nos princípios da universalidade $\mathrm{e}$ flexibilidade, com vistas a facilitar o gerenciamento de processos constituídos sob a sua égide ${ }^{24}$.

Também faz parte do movimento tendente à adoção dos meios alternativos em âmbito internacional os incentivos propugnados pela Comissão das Nações Unidas para o Direito Comercial Internacional (UNCITRAL), que tem por finalidade promover maior uniformização às

22 AZEVEDO, Monique Haddad Knochelmann Azevedo, et. al. Fundamentos da negociação para o ambiente jurídico. São Paulo: Saraiva. 2014, p. 36.

${ }^{23}$ Cf. ANDREWS, Neil. Formas Judiciais e Alternativas de Resolução de Conflitos na Inglaterra. (Trad.) WAMBIER. Teresa Arruda Alvim. São Paulo: Revista dos Tribunais. 2010.

${ }^{24}$ BASSO, Maristela. op. cit. p. 357. 
regras comerciais internacionais, aplicadas às relações estabelecidas entre particulares que estejam submetidos a diferentes legislações ${ }^{25}$.

Significa dizer que esses meios alternativos de solução de conflitos, individualizados, por meio de métodos com características diferentes, têm suas nuances próprias; entretanto apresentam algo de similar, que faz parte de uma interpretação jurídica comum e que promovem a construção de um direito comum em todo o mundo ${ }^{26}$, que guarda reciprocidade com os ordenamentos internos.

Os benefícios dos meios alternativos de solução de conflitos não podem, contudo, serem reduzidos à ideia de diminuição dos processos a serem levados ao Poder Judiciário e, por conseguinte, à possibilidade de que, com a demanda menor, a resposta seja satisfatoriamente alcançada. Isso reduziria a estruturação desses métodos a objetivos diferentes daqueles para o qual foram concebidos.

Assim, o objetivo primordial dos meios alternativos de solução de conflitos não é solucionar a crise de morosidade pela qual o Poder Judiciário vem passando, com a mencionada possibilidade de redução dos processos, mas sim oferecer às partes meios efetivos e adequados à solução de seus conflitos de interesse, assegurando o acesso à justiça de forma mais ampla ${ }^{27}$.

Essa, portanto, a premissa a ser seguida quando se pensa na estrutura dos mecanismos alternativos de solução de conflitos dentro de um sistema judicial: a busca pela solução adequada a partir da natureza do conflito e levando em conta a característica especial das partes envolvidas. Reduzir o número de processos é uma consequência espontânea dessa prática ${ }^{28}$.

\footnotetext{
${ }^{25}$ MUNIZ, Tânia Lobo. Arbitragem no Brasil e a Lei 9.307/96. Curitiba: Juruá. 2009, p. 160.

${ }^{26}$ VARELLA, Marcelo. op. cit. p. 445.

27 WATANABE, Kazuo. Acesso à justiça e meios consensuais de solução de conflitos in Tribunal Multiportas
}

O Tribunal Multiportas americano, baseiase nessa premissa, de que cada conflito deve ser resolvido pelo método mais adequado às suas características essenciais, situação que reforça a garantia fundamental de acesso à justiça, e, consequentemente, leva as partes a uma ordem jurídica mais justa.

Não basta que seja disponibilizado no Brasil as $A D R s$ sem que cada um desses mecanismos seja direcionado de maneira adequada e se interrelacionem, também ao lado do processo judicial comum, para formar um sistema de solução de controvérsias que vá além de, formalmente, garantir o acesso à justiça.

Dessa forma, o Tribunal Multiportas deve ser pensado exatamente na coordenação entre todos os meios alternativos dispostos no Brasil, baseando a escolha do método a partir do conflito de interesses a ser resolvido, axioma que deve nortear a ideia de estabelecê-lo em nossa realidade.

Desse ambiente, tem relevo a avaliação do conceito de Tribunal Multiportas estabelecido nos Estados Unidos em relação ao modelo adotado no Brasil, a fim de se compreender qual a interpenetração das estruturas e propostas apresentadas e o grau de implantação da ideia entre nós, a partir de bases iniciais do que se denomina sistema multiportas de solução de conflitos.

\section{O TRIBUNAL MULTIPORTAS: EXPERIÊNCIA AMERICANA}

O conceito de Tribunal Multiportas foi desenvolvido no Estados Unidos da América, a partir dos estudos em meios alternativos levados

- Investindo no capital social para maximizar o sistema de solução de conflitos no Brasil. (Org.) CRESPO, Maria Hernandez. Rio de Janeiro: FGV Editora, 2012, p. 89.

${ }^{28}$ WATANABE. Loc. cit. 
a termo pelo professor da Harvard Law School, Frank Sander ${ }^{29}$. Nessa parte, dentro do tema proposto, proceder-se-á a exposição da triagem inicial feita por Tribunais Multiportas nos Estados Unidos bem como da estrutura empregada nestas instituições, servindo como parâmetro para, ao final, revelar a fase em que se encontra a experiência brasileira em sistema multiportas.

A ideia do Tribunal Multiportas nasceu em 1975, quando o pesquisador mencionado estudava Direito de Família na Suécia, e remeteu alguns de seus estudos, baseados em meios alternativos, ao presidente da Suprema Corte dos Estados Unidos, Warren Burger que, em seguida, convidou-o a proferir a palestra de abertura de uma conferência em St. Paul, no estado de Minessota, onde ele ficaria encarregado de apresentar um documento sobre a solução de conflitos $^{30}$.

Naquela ocasião, foi a palestra denominada "Variedades de processamento de conflitos", posteriormente transformada em paper publicado na revista da American Bar Association (ABA), equivalente à Ordem dos Advogados do Brasil, na qual se denominou o conceito criado pelo professor como "Tribunal Multiportas" 31.

Sobre o estabelecimento de um sistema multiportas de solução de conflitos, Frank Sander ${ }^{32}$ levanta quatro pilares para a sua instituição efetiva, a saber: (i) a institucionalização dos meios alternativos de solução de conflitos; (ii) a escolha do método a partir de uma triagem feita por um expert; (iii) adequada formação dos profissionais que irão manejar o conflito a partir destes métodos, incluindo advogados e mediadores/conciliadores;

\footnotetext{
${ }^{29}$ SALES, Lilia Maia de Morais; SOUSA, Maria Almeida de. A Mediação e os ADR'S (Alternative Dispute resolutions) - A Experiência norte-americana, in Revista Novos Estudos Jurídicos - Eletrônica, Vol. 19 - n. 2 - maiago 2014, p. 380.

${ }^{30}$ Ibidem. Loc. cit.

${ }^{31}$ Ibidem. p. 381
}

(iv) existência de uma política pública de conscientização sobre os benefícios de adotar os meios alternativos, além da adequação da destinação de recursos bem como sobre a economia a ser gerada no sistema judiciário com o incentivo à utilização dos Meios Alternativos de Solução de Conflitos - MASC.

A concepção parte do pressuposto de que é necessário avaliar, a partir das características do conflito, a adequação dos variados meios para solução de controvérsias, tais como mediação, conciliação, arbitragem e negociação. Feita a análise de cada um dos métodos aptos à solução de conflitos, sempre a vista da relação conflituosa, prossegue-se à verificação de seus procedimentos a fim de buscar quais portas - meios - seriam adequadas a cada um dos conflitos que nasçam das relações sociais ${ }^{33}$.

O problema do acesso à justiça em tempo hábil é complexo e, por conta de sua proporção, requer uma solução conjunta, que envolva todos os atores sociais que lidam com os conflitos de interesse, inclusive as próprias partes. Por isso, a abordagem sistêmica deve ser iniciada com uma perspectiva inclusiva, em termos de política pública, capaz de integrar todas as partes envolvidas em todo o processo, otimizando, dessa forma, a resolução de $\operatorname{conflitos}^{34}$.

Essa otimização da garantia de acesso à justiça envolve a necessidade de que a disputa em debate seja inclinada para o fórum mais adequado àquela controvérsia ${ }^{35}$. Surge daí o conceito de fórum multiportas ou de um sistema multiportas de solução de controvérsias, uma noção mais democrática de justiça, pois leva em conta o destinatário do serviço judiciário, permitindo a

\footnotetext{
${ }^{32}$ SANDER, Frank. Future of ADR, in Journal of Dispute Resolution. Issue 1, Article 5. University of Missouri School of Law Scholarship Repository, 2000, p. 3-5.

${ }^{33}$ CRESPO, Maria Hernandez. et. al. (Coord.). Op. Cit., p. 30-31.

${ }^{34}$ Ibidem. p. 43.

${ }^{35}$ SANDER, Frank. Op. Cit. p. 3.
} 
participação efetiva das partes em conflito na escolha do método mais adequado aos seus problemas, o que requer, em certa medida, a institucionalização deste modelo.

Nesse contexto as partes envolvidas em um conflito disporiam não só dos mecanismos habituais para a solução de seus conflitos, notadamente os tribunais, mas também, nestas mesmas instituições, poderiam se valer de métodos alternativos à solução de disputas, que seriam definidos a partir da divergência apresentada, ideia que tem a capacidade de auxiliar na consolidação da garantia fundamental de acesso à justiça.

Passando ao objeto que será analisado, especialmente o modelo de triagem e estrutura dos organismos em questão, é importante destacar que o funcionamento do Tribunal Multiportas advém de seu próprio conceito, e consiste no direcionamento do conflito, a partir de suas especificidades, à porta mais adequada para a sua solução, criando-se, dessa maneira, um modelo de organização judiciária multifacetado ${ }^{36}$. Dessa forma, o recorte neste tópico levará em conta os procedimentos de triagem e de seleção/formação de mediadores e conciliadores nos Tribunais Multiportas instalados Connecticut, Washington D.C e New Jersey.

Assim, o Tribunal Multiportas pode ser definido como um dos mecanismos funcionais da onda reformista do Poder Judiciário, mencionada aqui no início deste trabalho. Nos Estados Unidos constitui uma instituição que funciona de baixo para cima e que tem a finalidade de reencaminhar as ações para o fórum mais adequado, em vez de apontar que o julgamento através do processo

36 GONÇALVES, Vinícius José Corrêa. Tribunais Multiportas: Em busca de novos caminhos para a efetivação dos direitos fundamentais de acesso à justiça e à razoável duração dos processos. 2011. 224 f. Dissertação (Mestrado em Ciências Jurídicas) - Universidade Estadual do Norte do Paraná, p. 158. comum nos tribunais constitui o melhor caminho para as mesmas ${ }^{37}$.

$\mathrm{Na}$ prática, o funcionamento do Tribunal Multiportas se daria pela análise preliminar dos casos, que passariam por uma triagem em sua entrada no fórum, por meio de uma função de diagnóstico a ser exercida por funcionários capacitados, para verificar as descrições do conflito que são fornecidas pelas próprias partes para então direcioná-los à porta mais adequada à solução ${ }^{38}$. Para compor a delimitação aqui pretendida, de forma exemplificativa, selecionouse alguns estados americanos com programas multiportas para expor a triagem dos conflitos que são levados à essas cortes bem como sua estrutura de funcionamento.

No Multi-Door Dispute Resolution Division of the D.C Superior Court, o processo de triagem remete grande parte dos conflitos à mediação, por conta das vantagens obtidas com o método, à exceção daqueles que envolvam armas, lesões graves, violência doméstica, abuso de menores ou diferença do poder de barganha entre as partes em disputa $^{39}$. Nas small claims courts, existentes no mesmo Estado, o encaminhamento feito é obrigatório $^{40}$.

De outro lado, no Estado de Connecticut, a regra para a triagem e encaminhamento do conflito é baseada na arbitrariedade do juiz e/ou vontade das partes, exceto em programas de aplicação específica existentes no Estado em questão, como o da family division e o da mortgage forecolesure (execução de hipoteca), nos quais, antes de entrarem com processos contenciosos, são as partes encaminhadas à mediação $^{41}$.

\footnotetext{
${ }^{37}$ CRESPO, Maria Hernandez. et. al. (Org.). Op. Cit. p. 80.

${ }^{38}$ GONÇALVES, Op. Cit., p. 161.

${ }^{39}$ ASPERTI, Maria Cecília de Araújo. Op. Cit, p. 120.

${ }^{40}$ Ibidem, Loc. Cit.

${ }^{41}$ Ibidem, Loc. Cit.
} 
Por seu turno, no Estado de New Jersey, está estabelecido o Complementary Dispute Resolution of the State Court of New Jersey, instituição muito valorizada e que compõe importante parte do sistema de gerenciamento de processos naquele estado ${ }^{42}$. Por lá, o encaminhamento dos processos, feito após a distribuição, aos métodos de solução de disputas, depende de uma classificação, realizada já neste momento, quando se insere um track específico de tramitação, com uma primeira sessão de mediação, a qual é obrigatória ${ }^{43}$.

Dessa forma, as disputas são encaminhadas a diversos mecanismos de solução de conflitos centralizados em um só lugar, mediante critérios de triagem definidos em lei ou nas normas administrativas judiciais, podendo também ser remetidos por juízes com base em critérios prédefinidos, ou, ainda, dentro do que se mencionou sobre a participação maior das partes na administração da justiça, serem definidos a sua escolha. Mencione-se também a possibilidade de que o legislador ordinário defina que certos conflitos sejam, de forma mandatória ou voluntária, submetidos a determinados mecanismos ${ }^{44}$.

Independentemente da forma pela qual o conflito é encaminhado à porta adequada, é essencial que as suas características sejam examinadas $^{45}$. Esse é, ao mesmo tempo, o atributo central e a maior virtude do fórum multiportas, pois permite que conflitos/controvérsias/disputas

os

\footnotetext{
${ }^{42}$ Ibidem, Loc. Cit.

${ }^{43}$ ASPERTI, Op. Cit., p. 121.

${ }^{44}$ ASPERTI, Op. Cit., p. 75.

${ }^{45}$ Asperti, Loc. Cit.

${ }^{46}$ Expressão Mencionada por Frank Sander à professora Maria Hernandez Crespo em entrevista retratada no livro Tribunal Multiportas: investindo no capital social para maximizar o sistema de solução de conflitos no Brasil. Quando da criação de seu sistema de solução de conflitos não o nomeou como Tribunal Multiportas, mas sim como "Centro Abrangente de Justiça". A expressão Tribunal
}

direcionados a partir da reconstrução da divergência, partindo do problema para alcançar a solução, e não no sentido contrário, como faz o sistema judiciário como se encontra hoje, ao colocar o processo comum como única alternativa possível a qualquer conflito de interesses, numa perspectiva adversarial.

Considerando o funcionamento do Tribunal Multiportas da forma como idealizado por Frank Sander, Marco Antônio Garcia Lopes Lorencini sugere os seguintes critérios para a triagem dos conflitos a ser efetuada no centro de abrangência de justiça ${ }^{46}$ : (i) escolha do meio ser feita pelo autor, (ii) ou pelo réu, ou (iii) por ambos de forma consensual. Pode ainda ser feita (iv) mecanicamente por um funcionário do tribunal, por (v) um perito externo ou, ainda, (vi) pelo próprio julgador ${ }^{47}$.

Entretanto, é possível chegar a um denominador comum com relação aos meios alternativos para solução de conflitos e o seu direcionamento, sendo que o processo judicial é mais indicado a conflitos de interesse público e direitos indisponíveis, ao passo que a mediação e a conciliação almejam a construção autocompositiva da controvérsia, além da arbitragem que envolve um viés técnico e heterocompositivo, baseada sempre na especialidade da sentença arbitral $^{48}$.

Quanto às finalidades dos programas aqui destacados, o Multi-Door Dispute Resolution Division of the D.C Superior Court tem como objetivo facilitar o acesso à justiça, evitar

Multiportas, hoje popularizada nos Estados Unidos fora concebida pela ABA - America Bar Association - em artigo publicado em periódico no ano de 1976, como menciona o mesmo Frank Sander na entrevista aludida acima (Op. Cit. p. 32).

${ }^{47}$ LORENCINI, Marco Antonio Garcia Lopes. Prestação jurisdicional pelo Estado e meios alternativos de solução de controvérsias: convivência e formas de pacificação social. Tese (Doutorado) - Universidade de São Paulo, São Paulo, 2006, p. 117.

${ }^{48}$ GONÇALVES, Op. Cit. p. 163. 
delongas e disponibilizar uma rede de solução de disputas e, apesar de colocar à disposição uma série de métodos de solução de conflitos, trabalha hoje com mediação facilitativa e arbitragem ${ }^{49}$.

A outra experiência de Tribunal Multiportas aqui destacada é a que tem lugar no estado americano de Connecticut. O ADR office lá instalado tem também como objetivo oferecer mecanismos de disputas que não judiciais à solução de conflitos, trabalhando com os processos mais usuais, além daqueles mais incomuns ${ }^{50}$.

Mencione-se ainda a Complementary Dispute Resolution Division of the State Court of New Jersey, que possui objetivo maior, consistente em criar regras, parâmetros de seleção de mediadores, treinamento de árbitros, além de promover o desenvolvimento de mecanismos uniformes de coleta de dados, entendendo-se que os processos de resolução de disputas são complementares e não alternativos ao processo judicial comum ${ }^{51}$.

Partindo para a exposição da estrutura desses programas, no que se refere aos profissionais que o integram, o Multi-Door de D.C conta com mediadores voluntários, ao passo que em Connecticut, as mediações são realizadas por juízes voluntários, enquanto em outros programas os mediadores são vinculados ao Poder Judiciário $^{52}$. Importante anotar que nenhum dos programas mencionados exige o pagamento de custas às partes para a prestação dos serviços judiciários ${ }^{53}$.

O programa estabelecido em Connecticut é o único, dentre os mencionados, em termos de estrutura, que não apresenta um escritório central para o direcionamento dos processos por todo o território do estado, situação que dificulta a intercomunicação entre os programas existentes no território, funcionando de forma desconectada nas localidades, com relação à regulação, promoção de treinamentos, e até mesmo no angariamento de recursos voltados à prática de meios alternativos por lá ${ }^{54}$.

Importante anotar ainda que, quanto à possibilidade de se obter assistência judiciária, a small claims courts de Washington conta com um organismo próprio chamado de small claims resource office, mantendo também convênios com instituições que oferecem assistência e orientação jurídica de forma gratuita. No Estado de Connecticut o Poder Judiciário vem investindo em projetos de oferecimento de orientação jurídica gratuita, enquanto New Jersey procura trabalhar com advogados pro bono, que realizam plantões nos fóruns ${ }^{55}$.

Assim, estas experiências concretas implementadas nos Estados Unidos mostram, mesmo que de maneiras distintas, a preocupação em atender aos pressupostos estabelecidos por Sander. Existe a preocupação em formar adequadamente

mediadores/conciliadores/advogados, procura-se estabelecer também políticas públicas que incentivem a utilização das $A D R s$, as cortes também têm se atentado à importância do profissional que fará a triagem (screening clerk), além da institucionalização que tem ocorrido em todas as instâncias.

Portanto, dentro do que se expôs, na realidade norte-americana cada porta destinada à solução de controvérsias tem suas especificidades, que devem ser levadas em conta para a proposição de resolver os conflitos a ela submetidos, para que as partes não encontrem, ao invés de facilidades, dificuldades no tratamento

\footnotetext{
${ }^{53}$ Ibidem, p. 120.

${ }^{54}$ GABBAY, Daniela Monteiro. Op. Cit., p. 138.

${ }^{55}$ ASPERTI, Op. Cit., p. 121-122.
} 
de seus casos concretos, o que envolve uma série de fatores que vão muito além da centralização das ADRs num único local.

É por isso que, para além de estabelecer um fórum com variados procedimentos disponíveis à solução de conflitos, é preciso que a reforma do judiciário signifique uma coordenação com outras ações, ao lado da promoção dos métodos alternativos de solução de conflitos, o que pressupõe o repensar de todo o instrumental disponível às partes ${ }^{56}$. Chega-se, com esse pensamento sistêmico, à noção de um sistema multiportas.

Traçar a ideia de sistema multiportas, em vista desta constatação, vai muito além de deixar à disposição das partes em conflito um emaranhado de procedimentos estabelecidos em lei para solucionar suas controvérsias, exigindo a participação efetiva daqueles que compõem a sociedade nesse processo de reforma, além da indispensável reconstrução da cultura jurídica ${ }^{57}$, marcada, em muito, pela ideia de litigiosidade.

A noção de sistema tem a ver com a ideia de harmonia, regularidade, e estruturação, e, para pensar o sistema, existe a necessidade de que os seus elementos estejam concatenados, o que exige a interligação entre as diversas categorias de elementos em relação contínua, levando à unidade sistemática, a coerência estrutural, além da completude $^{58}$.

Um sistema multiportas de solução de conflitos, ante a definição de sistema colocada acima, deve disponibilizar aos pretensos litigantes mecanismos para a solução de conflitos dialogicamente relacionados e pensados à solução das controvérsias de maneira efetiva. Devem ainda estar previstos no ordenamento positivo, e colocados de forma a produzirem soluções dotadas de eficácia material e que sejam também definitivas.

Os processos destinados à solução de controvérsias e litígios devem ser coordenados pelo ordenamento jurídico e devidamente direcionados, para que construam verdadeiramente um sistema multiportas de solução de conflitos, e sejam considerados como autônomos, e, assim, realizem os seus fins, ajudando a consolidar as ondas de acesso à justiça idealizadas por Garth e Capelletti. É possível falar-se nos Estados Unidos na consolidação da noção de sistema multiportas de solução de conflitos, não obstante ser necessário contínuo aperfeiçoamento.

A prática por lá, quando se fala em Tribunal Multiportas, apesar de avançada, tem muitos desafios a serem ainda superados, pois, conforme afirmado no início deste capítulo, existe a necessidade de serem estabelecidos os pilares fundamentais de funcionamento do conceito que se apresenta. Um dos atributos a serem valorados melhor pelo sistema norte-americano é uma preocupação maior com a ideia de uniformização dos programas analisados, notadamente quanto à triagem bem como no que se refere à formação dos profissionais envolvidos.

Seguindo, a partir destes pressupostos, é possível definir a realidade brasileira de tratamento de conflitos de interesse, levando em conta as premissas referentes aos Tribunais Multiportas estabelecidos no sistema multiportas dos Estados Unidos.

\footnotetext{
${ }^{56}$ CRESPO, Maria Hernandez. et. al. (Org.). Op. Cit. p. 56.

57 Neste sentido Frank Sander afirma existirem impedimentos de ordem prática para que advogados evitem a utilização dos meios alternativos. Um deles consiste na falta de controle por eles dos procedimentos inerentes à mediação, por exemplo, que exigem a participação maior
}

das partes, além disso, existem também incentivos econômicos para que a litigância permaneça alta, como com os honorários advocatícios. SANDER, Op. Cit. p. 4. 58 ALMEIDA, Guilherme Assis de. BITTAR, Carlos Alberto. Curso de Filosofia do Direito. São Paulo: Atlas. 2010, p. 579. 
3 SOBRE A INSTITUIÇÃO DE TRIBUNAIS MULTIPORTAS NO BRASIL

Em virtude das evoluções apontadas é que a procura pelos meios alternativos tem aumentado também no Brasil. Dentre muitos benefícios apontados pela doutrina ${ }^{59}$, a respeito da utilização dos meios alternativos de solução de conflitos, são em geral mencionados: a solução de controvérsias em tempo adequado, o tratamento de conflitos a partir de sua especificidade, o desafogo do Poder Judiciário, a participação mais democrática das partes na decisão a ser alcançada, além do fator econômico existente na comparação entre $A D R s$ e o processo comum.

A necessidade da evolução do sistema de solução de conflitos se dá também, em grande parte, por conta do crescimento dos movimentos sociais - os quais centralizaram a defesa dos direitos humanos, comunidades de base, comissões eclesiais de base, movimentos de minorias, sindicatos, organizações não governamentais -, que emergiram entre os anos 70 e 90, procurando ampliar, a partir de então, o acesso dos segmentos marginalizados e pobres da população brasileira à justiça ${ }^{60}$.

De igual forma, caminha ao lado desse contexto, a promulgação da Constituição Federal, em 1988, que levou ao ajuizamento de inúmeras ações judiciais, para que fossem - e ainda se procura esse estado ideal - reconhecidos os novos direitos estabelecidos, como aquele que garante a moradia, bem como, a título de exemplo, o inerente à implementação da reforma agrária,

\footnotetext{
${ }^{59}$ Cf. WATANABE, 2014, p. 3; GARTH e CAPELLETTI. op. cit., 2002, p. 11-15.

${ }^{60}$ FARIA, José Eduardo. Direito e Justiça no Século XXI: a crise da Justiça no Brasil. Coimbra/Portugal. Seminário Direito e Justiça no Século XXI, 2003. Disponível em:

$<$ http://opj.ces.uc.pt/portugues/novidds/comunica/JoseEdu arFaria.pdf>, p. 06. Acesso em: 03 out. 2017.

${ }^{61}$ Ibidem. Loc. Cit.
}

provocando a movimentação da burocrática máquina judiciária brasileira para atender às novas demandas surgidas a partir de então ${ }^{61}$.

É dessa forma que surgiu a necessidade de se reformar o Poder Judiciário no Brasil, notadamente por conta dos complexos processos de ascensão dos direitos sociais e da globalização. Uma parte dessa onda reformista envolve a adoção e incentivo dos MASCs (Meios Alternativos de Solução de Conflitos), o que gerou a atenção do legislador e da doutrina especializada em relação aos procedimentos de mediação, conciliação e arbitragem, importando analisar a experiência brasileira em solução de conflitos à luz dos quatro pilares definidos por Sander para se estabelecer um sistema multiportas.

A mediação tem uma lei especial dedicada somente aos seus procedimentos, a qual foi recentemente editada, recebendo $o \mathrm{n}^{\circ}$ 13.140/2015, que trata nas suas disposições do procedimento de mediação judicial e extrajudicial, da qualificação dos mediadores, e também dos conflitos que podem ser submetidos a esse processo. Ainda, o novo Código de Processo Civil cuidou da mediação em diversos dispositivos ${ }^{62}$, dispondo sobre o incentivo à mediação, à necessidade de audiências de mediação $\operatorname{logo}$ após a citação, assim como instituiu seus princípios fundamentais.

Por sua vez a conciliação tem tratamento no novo Código de Processo Civil, devendo ser incentivada por todos os atores do sistema judiciário brasileiro ${ }^{63}$, constituindo procedimento

${ }^{62}$ Dentre todos cite-se os artigos $3^{\circ}, 165,166,167,168,169$, $173,174,250,303,308,334,335,359,545$ e 694.

${ }^{63}$ Novo Código de Processo Civil, art. $3^{\circ}$, parágrafo $3^{\circ}$ :

Art. 3o Não se excluirá da apreciação jurisdicional ameaça ou lesão a direito.

§ 3o A conciliação, a mediação e outros métodos de solução consensual de conflitos deverão ser estimulados por juízes, advogados, defensores públicos e membros do Ministério Público, inclusive no curso do processo judicial. 
que deve ser buscado a todo o tempo, além de colocar o conciliador judicial como auxiliar da justiça, devendo atuar, preferencialmente, em casos nos quais não exista vínculo anterior entre as partes ${ }^{64}$.

Já a arbitragem é regulada no Brasil pela Lei 9.307/96, que cuida do procedimento arbitral, das convenções de arbitragem, da sentença a ser proferida pelo árbitro, além do modo pelo qual se executam estas sentenças. Importante anotar que no plano internacional ela é regulamentada no Brasil pela Convenção de Nova York, internalizada pelo Decreto n. 4.311/2002, pela Convenção Interamericana sobre Arbitragem Comercial Internacional, objeto do Decreto $\mathrm{n}$. 1.902/1996, bem como pelo Acordo sobre Arbitragem Comercial Internacional do Mercosul, promulgada pelo Decreto $n$. 4.719/2003.

Assim é que, delimitado o conceito de Tribunal Multiportas, partindo da experiência norte-americana, pioneira, e dos influxos proporcionados pela utilização dos meios alternativos de solução de conflitos numa perspectiva mundial, na adoção destes mecanismos no Brasil, é essencial definir se essa concepção já está estabelecida por aqui, apoiando-se nos quatro pilares definidos anteriormente.

Importante determinar que a importação de conceitos jurídicos não pode ser mecanizada, pois essa prática pode causar efeitos completamente distintos quando utilizados em culturas jurídicas diferentes ${ }^{65}$, razão pela qual a tradução conceitual que aqui é efetuada deve servir, em última análise, ao sistema brasileiro de solução de conflitos, com peculiaridades diversas do sistema americano, mas levando em conta os aspectos positivos que são verificados neste último.

\footnotetext{
${ }^{64}$ Dentre todos cite-se os artigos, $3^{\circ}, 165,166,167,168$, $169,173,174,250,303,308,334,335,359,545$ e 694.
}

O conceito, por conta do que se mencionou no parágrafo acima, deve ser encarado sob a perspectiva da experiência brasileira em resolução de conflitos, o que, saliente-se, deve se relacionar também com o nosso sistema judiciário. Não se pode deixar de lado também a ideia de revolução sistêmica, raciocínio que envolve muito mais do que incentivar a resolução de controvérsias por meio de ADRs.

Partindo do conceito de Tribunal Multiportas, bem como de sua introdução numa abordagem sistêmica de reforma do Poder Judiciário no Brasil, é essencial traçar linhas gerais sobre o seu funcionamento, em termos de estrutura, para contribuir, em parte, com a consolidação da garantia fundamental de acesso à justiça.

Antes de passar propriamente à institucionalização do Tribunal Multiportas, assim como concebido nos Estados Unidos, no Brasil é essencial fazer uma diferenciação a respeito de Tribunal Multiportas e Sistema Multiportas, dada a evidente distinção conceitual que as expressões importam. Sistema, como mencionado anteriormente, envolve uma ideia maior, de harmonia e estruturação geral, ao passo que o Tribunal Multiportas significa institucionalizar a escolha dos MASCs, ao lado do processo comum, como portas disponíveis nas cortes brasileiras.

Nesse passo, segue-se no Brasil o caminho à consolidação de um sistema multiportas de solução de conflitos, e prova disso é a edição da Lei de Arbitragem em 1996, recentemente reformada para estruturar melhor seu procedimento, bem como a edição da Lei 13.140/2015 que trata da mediação judicial e extrajudicial, além da entrada em vigor do novo Código de Processo Civil, que procurou em todo

65 ESTEVES, João Luiz Martins. O Comando Político Jurídico da Constituição: Ideologia e Vinculação Hermenêutica. Rio de Janeiro: Lumen Iuris. 2016, p. 252. 
o seu texto, conforme já se citou aqui, incentivar a adoção de técnicas alternativas de solução de controvérsias, se relacionando, assim, com o quarto pilar fixado por Sander ${ }^{66}$

Tem-se procurado na cultura jurídica brasileira, e essa afirmação parte das constatações já deduzidas, um desapego ao litígio e, como resultado, a valorização dos meios alternativos de solução de conflitos no Brasil, deixando de ser o processo a única via possível. Pode-se afirmar, por conta disso, que estamos caminhando à construção de um sistema multiportas de solução de conflitos.

É interessante, contudo, fazer uma análise comedida do movimento de acesso à justiça pelos meios alternativos de solução de conflitos. Obviamente a adoção desses meios é um fato positivo, no entanto, a continuidade do movimento sem controle ou disciplina gerará alguns riscos sérios, como falta de qualidade dos serviços prestados pelos mediadores/conciliadores, atuação de pessoas e instituições sem preparo, e também a execução de atividades conciliatórias por aqueles que desejam fazer dos meios alternativos fonte de receitas imerecidas $^{67}$.

Ainda, no que se refere às etapas necessárias à consolidação de um sistema multiportas de solução de conflitos no Brasil, anota-se que hoje tudo está "muito solto" nos vários setores do judiciário nacional, e em diversas áreas da sociedade brasileira (escolas, entidades de classe, instituições privadas, empresas, etc.); as boas experiências estão aí e colhem resultados, mas existe, de outro lado, um grande risco, consistente na falta de uniformidade

\footnotetext{
${ }^{66}$ Um sistema multiportas exige a adoção de uma política pública de conscientização sobre a necessidade de se utilizar os MASCs, envolvendo seus aspectos econômicos e principalmente a noção democrática decorrente do seu conceito.
}

na prática dos meios consensuais de solução de conflitos $^{68}$.

Não existe, com relação ao terceiro ponto levantado - formação e treinamento daqueles que irão trabalhar com o sistema multiportas, uniformidade nas práticas que procuram institucionalizar os meios alternativos de solução de conflitos, e esse aspecto impede, ao menos por ora, que se considere estabelecido no Brasil, de maneira plena, um sistema multiportas de solução de conflitos. Em São Paulo, por exemplo, o serviço de conciliação é prestado de forma voluntária, ao passo que em Estados como a Bahia a conciliação fica a cargo de um funcionário especializado da justiça que é remunerado, e, em outros, como o Rio Grande do Sul, ela é promovida pelo Juiz Leigo, que recebe conforme a quantidade de atos praticados ${ }^{69}$.

Esse aspecto da estrutura do sistema multiportas brasileiro é semelhante ao que ocorre nos Estados Unidos. Mesmo com modelos federativos diferentes, as peculiaridades nos estados americanos com experiências concretas na implantação de sistemas multiportas mostrou realidades distintas na seleção dos mediadores/conciliadores, assim como ocorre no Brasil.

Quanto a este fator, para que os meios alternativos de solução de conflitos sejam adequadamente utilizados e se constituam como meio de conferir aos jurisdicionados verdadeiramente o acesso à justiça e à ordem jurídica justa, é necessário estabelecer uma política pública de tratamento de conflitos de interesses, que outorgue um mínimo de organicidade e controle à sua prática, fixando critérios e condições ao seu exercício,

\footnotetext{
${ }^{67}$ WATANABE, Op. Cit. p. 92.

${ }^{68}$ Ibidem, p. 93.

${ }^{69}$ Ibidem, Loc. Cit.
} 
estabelecimento de carga horária e métodos para a capacitação e treinamento dos conciliadores/mediadores ${ }^{70}$.

As linhas evolutivas do judiciário brasileiro apontam para a constituição de um sistema multiportas de solução de conflitos, diante das práticas apontadas, além da edição de diplomas normativos que cuidam da matéria, bem como a atenção dos pesquisadores do Direito a esses mecanismos. Entretanto, para que se possa afirmar estabelecido um sistema multiportas de solução de conflitos, existem passos a serem dados, especialmente, como mencionado acima, para dar unidade e organicidade, no que diz respeito à formação de mediadores/conciliadores, requisitos essenciais à formação de sua estrutura, o que já é uma realidade mais consolidada no ambiente americano, em que pese algumas diferenças conceituais expostas aqui.

De outro lado, há o conceito de Tribunal Multiportas, concebido nos Estados Unidos por conta das pesquisas do professor Frank Sander, conforme já exposto aqui, que se diferencia do que se entende por sistema multiportas de solução de conflitos. Consiste num centro integrado de solução de conflitos, no qual os litigantes serão direcionados ao método mais condizente com os fatos a serem solucionados. Faz parte, assim, do desenvolvimento adequado de um sistema multiportas de solução de conflitos, na perspectiva de sua institucionalização, mencionada anteriormente.

A concepção inicial parte da necessidade de observar as variadas formas de solução de

\footnotetext{
${ }^{70}$ WATANABE, Op. Cit., p. 93-94.

${ }^{71}$ CRESPO, Op. Cit., p. 32.

${ }^{72}$ CRESPO, Loc. Cit.

${ }^{73}$ Novo Código de Processo Civil, Art. 334. Se a petição inicial preencher os requisitos essenciais e não for o caso de improcedência liminar do pedido, o juiz designará audiência de conciliação ou de mediação com antecedência mínima de 30 (trinta) dias, devendo ser citado o réu com pelo menos 20 (vinte) dias de antecedência.
}

conflitos: mediação, arbitragem, negociação e "med-arb", examinando cada um dos processos a fim de encontrar algum tipo de taxonomia para aplicar aos conflitos e qual das portas disponibilizadas seriam mais convenientes à solução deles ${ }^{71}$. Todos eles devem estar dispostos num mesmo local para melhor conveniência das $\operatorname{partes}^{72}$.

Não existem no Brasil Tribunais Multiportas. As partes, ao procurarem resolver seus litígios, podem recorrer ao processo judicial comum, sendo possível que a solução seja alcançada pelos meios alternativos de forma endoprocessual - quando o acordo é celebrado nos próprios autos - ou extraprocessual, ocasião na qual a resolução é alheia ao processo. Existe ainda a possibilidade de estabelecer a convenção arbitral, que tem a função de afastar a jurisdição comum.

Existe uma vinculação muito grande entre a mediação/conciliação aos processos judiciais, constituindo etapas do procedimento e não meios autonomamente considerados, diferente do que ocorre nos Estados Unidos, onde os processos de triagem indicam qual será o método utilizado. Prova disso é o artigo $334^{73}$ do novo Código de Processo Civil, ao estabelecer que as partes serão citadas para comparecerem à audiência de conciliação ou mediação, para depois, nos parágrafos $4^{\circ}$ e $5^{\circ} 74$, do mesmo dispositivo, dispensar absolutamente os processos autocompositivos.

Por isso, os meios alternativos de solução de conflitos não são ainda institucionalizados no

\footnotetext{
[...]

${ }^{74} \S$ 4o A audiência não será realizada:

I - se ambas as partes manifestarem, expressamente, desinteresse na composição consensual;

II - quando não se admitir a autocomposição.

§ 50 O autor deverá indicar, na petição inicial, seu desinteresse na autocomposição, e o réu deverá fazê-lo, por petição, apresentada com 10 (dez) dias de antecedência, contados da data da audiência.
} 
Brasil, como portas disponíveis junto ao Poder Judiciário, razão pela qual não é possível estabelecer que existem Tribunais Multiportas por aqui, pois falta obrigatoriedade nos procedimentos de triagem, diferente da realidade americana exposta, deixando completamente às partes a decisão sobre qual porta será utilizada. Sobre esse aspecto, Frank Sander ${ }^{75}$ observa que a vinculação dos Tribunais Multiportas aos tribunais estatais é algo natural, porque é lá que a maioria dos conflitos se encontram, não se exigindo que sejam necessariamente vinculados a eles.

Afirmar que não se encontram os Tribunais Multiportas consolidados na realidade brasileira como se fez acima, não quer dizer, contudo, que não se prosseguiu na sua institucionalização. $\mathrm{O}$ novo CPC, por exemplo, estabelece no seu artigo $165^{76}$ a obrigatoriedade da criação dos centros judiciários de solução consensual de conflitos, órgãos responsáveis pelo desenvolvimento da conciliação e da mediação através da estrutura estatal, sendo possível dizer, por isso, que se caminha à consolidação do primeiro ponto levantado por Sander, que estabelece a necessidade de institucionalizar os MASCs.

\footnotetext{
${ }^{75}$ CRESPO, Op. Cit., p. 33. Em entrevista concedida à professora Maria Hernandez Crespo, Frank Sander expõe, quanto à ligação entre Tribunais convencionais e os Tribunais Multiportas, que "Não existe qualquer relação inerente. Penso, por outro lado, que se trata de uma relação bastante natural, por que os tribunais são o principal local de que dispomos, talvez o mais importante, para a resolução de conflitos. Assim, podemos argumentar que o Tribunal Multiportas deveria estar ligado aos tribunais, mas tecnicamente o centro abrangente da justiça [ou Tribunal Multiportas] que eu citei poderia estar bem separado dos tribunais. É mais ou menos o que Willie Suton, o ladrão de bancos que, quando indagado por que roubava bancos, respondeu: "é lá que está dinheiro". O Tribunal é o lugar onde os casos estão, portanto nada mais natural do que fazer do tribunal uma das portas do Tribunal Multiportas - a ideia é essa.

${ }^{76}$ Novo Código de Processo Civil, Art. 165. Os tribunais criarão centros judiciários de solução consensual de
}

Estes centros, entretanto, já tinham sido programaticamente previstos na Resolução $n$. 125/2010 do Conselho Nacional de Justiça, a qual, no seu artigo $8^{\circ} 77$, impõe aos Tribunais a obrigação de criar Centros Judiciários de Solução de Conflitos e Cidadania (Centros ou CEJUSCs), considerados pelo diploma normativo em questão como unidades efetivas do Poder Judiciário, situação compatível com a vivida nos Estados Unidos, que conta com a criação de centros especializados em meios alternativos junto às cortes estatais.

Outro passo dado, ao estabelecimento de Tribunais Multiportas no Brasil, também está presente no novo Código de Processo Civil, quando prevê, em seu artigo $167^{78}$, a possibilidade de criação de câmaras privadas de mediação e conciliação, além da atuação privada de mediadores e conciliadores de forma extrajudicial, hipótese também amparada na já mencionada Lei $13.140 / 2015$, que cuida dos processos de mediação e conciliação.

Apesar desses louváveis avanços, obtidos recentemente entre nós, existe um aspecto fundamental para que os Tribunais Multiportas não estejam, ainda, num grau mais avançado de evolução: a existência de alguém, seja em

conflitos, responsáveis pela realização de sessões e audiências de conciliação e mediação e pelo desenvolvimento de programas destinados a auxiliar, orientar e estimular a autocomposição.

${ }^{77}$ Art. $8^{\circ}$ Os tribunais deverão criar os Centros Judiciários de Solução de Conflitos e Cidadania (Centros ou Cejuscs), unidades do Poder Judiciário, preferencialmente, responsáveis pela realização ou gestão das sessões e audiências de conciliação e mediação que estejam a cargo de conciliadores e mediadores, bem como pelo atendimento e orientação ao cidadão.

78 Novo Código de Processo Civil, Art. 167: Os conciliadores, os mediadores e as câmaras privadas de conciliação e mediação serão inscritos em cadastro nacional e em cadastro de tribunal de justiça ou de tribunal regional federal, que manterá registro de profissionais habilitados, com indicação de sua área profissional. 
câmaras privadas de mediação ou nos fóruns e Cejuscs, com a função de fazer a triagem dos conflitos. Esses profissionais são chamados nos Estados Unidos de intake staff ou screening officers $^{79}$.

Isso porque a ideia concebida por Frank Sander tem o objetivo fundamental de direcionar a solução dos conflitos para a porta com maior nível de efetividade, diante dos critérios definidores já mencionados aqui. Ao estabelecer a possibilidade de criação de Centros Judiciários, destinados à mediação e à conciliação, a nova lei processual peca do mesmo modo quando disponibiliza o processo às partes: coloca o meio sem fornecer parâmetros para definir qual deles obterá melhores resultados, mostrando grave distinção em relação ao sistema norte-americano, não existindo no sistema brasileiro qualquer procedimento mais complexo que possa atender ao segundo ponto estabelecido como pilar de um sistema multiportas.

Dessa forma, não se pode afirmar que está fixado no Brasil o conceito de Tribunal Multiportas, da mesma forma que não é possível dizer constituído um sistema multiportas, pois existem ainda obstáculos a serem transpostos, para que, a experiência de sistema judiciário vivida no Brasil possa ser, guardadas as particularidades, comparada às experiências norte-americanas que procuraram institucionalizar esse tipo modelo.

O caminho para a consolidação dos modelos aqui examinados está sendo trilhado e vem evoluindo assim como nos Estados Unidos, sendo acertado concluir que devem continuar a serem implantados gradativamente, avançando em termos de (i) institucionalização dos meios alternativos - através dos CEJUSCs, (iii) formação dos profissionais e advogados envolvidos no sistema de justiça e (iv) na existência de políticas públicas e estudos em termos de MASCs, somente faltando grandes avanços no que concerne (ii) aos procedimentos de triagem, panorama que, mantido, acabará resultando em maior efetividade da garantia fundamental de acesso à justiça.

\section{CONCLUSÃO}

Dentro do que se propôs, de uma análise entre o sistema de meios alternativos de solução de conflitos no Brasil e do conceito de Tribunal Multiportas efetivamente estabelecido nos Estados Unidos, a partir das influências da constatação da existência de novas relações humanas, a pesquisa realizada propiciou uma série de conclusões.

A primeira delas é refletida pelo processo de globalização que tem transformado as relações humanas de maneira muito acentuada, a partir da década de 80, do século XX. Esse movimento fez com que a interação fosse mais rápida, muito por conta das transformações tecnológicas, permitindo, a título de exemplo, que contratos fossem celebrados em questão de instantes por contratantes situados em diferentes partes do globo. O Direito não estava apto a esse choque, sendo necessário dar respostas a questões nunca antes debatidas.

Ao lado desse processo caminhou também a ascensão de novos direitos. Neste mesmo marco histórico passou-se a tutelar com maior efetividade os direitos sociais e os direitos difusos, fazendo com que se instalassem novas demandas junto ao Poder Judiciário para que fossem eles estabelecidos no plano concreto. A própria população passou a conhecer seus direitos

79 GOLDBERG, Stephen B.; SANDER, Frank E. A.; ROGERS, Nancy H.; COLE, Sarah Rudolph. Dispute

Resolution: negotiation, mediation and other processes. 5th ed. New York: Aspen Publishers, 2007, p. 350. 
de forma mais clara, e a requerê-los ao EstadoJuiz.

Esses dois fatores acentuaram a procura pelo sistema de justiça, o que contribuiu em muito para o que se denomina hoje "crise do judiciário". O processo comum, dentro dessa realidade, não é capaz de dar a resposta ao jurisdicionado de forma adequada e efetiva. Surgiu assim a necessidade de pensar em reformas do sistema até então centralizado neste modelo, e uma delas propugna pela adoção dos meios alternativos de solução de conflitos.

Assim é que o Brasil tem incentivado cada vez mais a adoção de meios alternativos de solução de conflitos, como resposta à crise vivida pelo Poder Judiciário, inapto à sua principal função, com a adoção de princípios e regras relativas à mediação e à conciliação, bem como a recente Lei 13.140/2015, que trata do processo de mediação. É preciso, contudo, mais do que isso, pois uma mudança sistemática exige a contribuição de todos os envolvidos na consolidação da garantia fundamental de acesso à justiça.

Essa atenção do sistema brasileiro é reflexo do sistema norte-americano de solução de conflitos, força motriz dessa mudança sistemática, pois influenciado pelas tendências acima delineadas, bem como por experiências internacionais engendradas em outros países, estabeleceu uma série de pautas envolvendo os Alternative Dispute Resolution, como resposta parcial à massificação de conflitos experimentada no mundo todo em decorrência dos processos acima delineados.

Dentro desse panorama é que Frank Sander propôs o conceito de Tribunal Multiportas, definido como um centro abrangente de justiça, no qual são disponibilizados vários métodos de solução de conflitos, selecionados por uma triagem inicial feita e que leva em conta as características e padrões da controvérsia para instituir uma taxonomia adequada a cada um dos conflitos.

A grande inovação do conceito, pelo que se concluiu, revelando assim sua importância, é trazer os meios alternativos como métodos autônomos de solução de conflitos, afastando-se da ideia do processo contencioso convencional como única porta disponível para a função pacificadora da sociedade, considerando-se o método a partir do conflito apresentando e não os disponibilizando sem qualquer consideração específica.

Conclui-se também que sistema multiportas e Tribunal Multiportas são conceitos absolutamente distintos, sendo que o primeiro envolve todo o ordenamento jurídico e sua afinidade com os meios alternativos que, num sistema, deveriam ser tratados de maneira idêntica ao processo judicial convencional, conquanto a ideia de Tribunal Multiportas refere-se apenas à institucionalização dos MASCs.

Outra conclusão é a de que alguns fatores impedem que seja estabelecido no Brasil um sistema multiportas de solução de conflitos tal qual nos Estados Unidos, destacando-se, dentre eles, o apego ao litígio ainda existente em nossa realidade, a colocação dos meios alternativos de solução de conflitos como fases do processo judicial comum e não como processos autônomos, além da fase ainda inicial de implantação de câmaras de mediação, conciliação e arbitragem privadas.

Assim é que, dentro da análise do objeto de pesquisa ora proposto, não foi possível estabelecer que o sistema de solução de conflitos é multiportas no Brasil, nos moldes como se concebe nos Estados Unidos, bem como também não tem lugar na realidade brasileira a ideia de Tribunal Multiportas, conceito que faz parte do cotidiano americano.

Não se olvida, contudo, que têm se verificado no Brasil avanços nesse sentido, 
especialmente, quanto ao desenvolvimento do sistema multiportas, no grande incentivo dos meios alternativos levado a efeito pela recente política judiciária brasileira, bem como atenção maior das leis que disciplinam a matéria, além do comprometimento de todos com a construção da justiça através dos meios alternativos.

A principal conclusão, assim, é a de que os conceitos de sistema multiportas e de Tribunal Multiportas têm se desenvolvido no Brasil, não sendo ainda realmente estabelecidos como nos
Estados Unidos, por motivos de ordem cultural, econômica, de política judiciária, além falta de uniformização verificada aqui em termos de seleção de mediadores/conciliadores, bem como a inexistência de processos de triagem. Organizar um sistema multiportas efetivo, e conceber Tribunais Multiportas no Brasil, é um dos objetivos a serem perseguidos por nós para dar maior densidade à garantia fundamental de acesso à justiça.

\section{REFERÊNCIAS}

ALMEIDA, Guilherme Assis de; BITTAR, Carlos Alberto. Curso de Filosofia do Direito. São Paulo: Atlas. 2010.

ANDREWS, Neil. Formas Judiciais e Alternativas de Resolução de Conflitos na Inglaterra. (Trad.) WAMBIER. Teresa Arruda Alvim. São Paulo: Revista dos Tribunais, 2010.

ASPERTI, Maria Cecília de Araújo. Meios Consensuais de Resolução de Disputas Repetitivas: a conciliação, a mediação e os grandes litigantes do judiciário. 2014. Dissertação (Mestrado em Direito Processual Civil) - Faculdade de Direito da Universidade de São Paulo.

AZEVEDO, Monique Haddad Knochelmann Azevedo, et. al. Fundamentos da negociação para o ambiente jurídico. São Paulo: Saraiva. 2014.

BASSO, Maristela. Curso de Direito Internacional Privado. São Paulo: Atlas. 2016.

CARMONA, Carlos Alberto. Arbitragem e Processo: Um Comentário à Lei 9.307/96. 2a ed. rev. atual. ampl. São Paulo: Atlas. 2006.

BRASIL. Justiça em Números 2017: ano-base 2016/Conselho Nacional de Justiça - Brasília: CNJ, 2017.

. Decreto n. $^{\circ}$ 1.902, de 09 de maio de 1996. Promulga a Convenção Interamericana sobre Arbitragem Comercial Internacional, de 30 de janeiro de 1975. Diário Oficial da República Federativa do Brasil. Brasília, 10 mai. 1996. Disponível em: <http://www.planalto.gov.br/ccivil_03/decreto/1996/D1902.htm>. Acesso em: 20 out. 2017.

Lei $n^{\circ}$ 9.307, de 23 de setembro de 1996. Dispõe sobre a arbitragem. Diário Oficial da República Federativa do Brasil. Brasília, 24 set. 1996. Disponível em: <http://www.planalto.gov.br/ccivil_03/leis/L9307.htm>. Acesso em: 15 set. 2017. 
. Decreto.$^{\circ} 4.311$, de 23 de julho de 2002. Promulga a Convenção sobre o Reconhecimento e a Execução de Sentenças Arbitrais Estrangeiras. Diário Oficial da República Federativa do Brasil. Brasília, $242002 . \quad$ jul. 20 Disponível <http://www.planalto.gov.br/ccivil_03/decreto/2002/d4311.htm>. Acesso em: 17 out. 2017.

. Decreto n. ${ }^{\circ} 4.719$, de 04 de junho de 2003. Promulga o Acordo sobre Arbitragem Comercial Internacional do Mercosul. Diário Oficial da República Federativa do Brasil. Brasília, 05 jun. 2003. Disponível em: <http://www.planalto.gov.br/ccivil_03/decreto/2003/D4719.htm>. Acesso em: 20 out. 2017.

. Lei n. ${ }^{\circ} 13.105$, de 16 de março de 2015. Código de Processo Civil. Diário Oficial da República Federativa do Brasil. Brasília, 17 mar. 2015. Disponível em: <http://www.planalto.gov.br/ccivil_03/_ato2015-2018/2015/lei/113105.htm>. Acesso em: 12 set. 2017.

. Lei n. ${ }^{\circ} 13.140$, de 26 de junho de 2015. Dispõe sobre a mediação entre particulares como meio de solução de controvérsias e sobre a autocomposição de conflitos no âmbito da administração pública; altera a Lei no 9.469, de 10 de julho de 1997, e o Decreto no 70.235, de 6 de março de 1972; e revoga o $§ 2$ o do art. 6o da Lei no 9.469, de 10 de julho de 1997. Diário Oficial da República Federativa do Brasil. Brasília, 29 jun. 2015. Disponível em: <http://www.planalto.gov.br/ccivil_03/_ato20152018/2015/Lei/L13140.htm>. Acesso em: 12 set. 2017.

CRESPO, Maria Hernandez. et. al. (Coord.). Tribunal Multiportas - Investindo no capital social para maximizar o sistema de solução de conflitos no Brasil. Rio de Janeiro: FGV Editora, 2012.

DOLINGER, Jacob, TIBURCIO, Carmen. Direito Internacional Privado: Parte Geral e Processo Internacional. Rio de Janeiro: Forense. 2016.

ESTEVES, João Luiz Martins. O Comando Político Jurídico da Constituição: Ideologia e Vinculação Hermenêutica. Rio de Janeiro: Lumen Iuris. 2016.

GABBAY, Daniela Monteiro. Mediação \& Judiciário: Condições necessárias para a institucionalização dos meios autocompositivos de solução de conflitos. 2011. Tese (Doutorado em Direito) - Faculdade de Direito da Universidade de São Paulo.

GARTH, Bryan, CAPELLETTI, Mauro. Acesso à Justiça. Porto Alegre: Sergio Antonio Fabris Editor. 2002.

GOLDBERG, Stephen B.; SANDER, Frank E. A.; ROGERS, Nancy H.; COLE, Sarah Rudolph. Dispute Resolution: negotiation, mediation and other processes. 5a ed. New York: Aspen Publishers, 2007.

GONÇALVES, Vinícius José Corrêa. Tribunais Multiportas: Em busca de novos caminhos para a efetivação dos direitos fundamentais de acesso à justiça e à razoável duração dos processos. 2011. Dissertação (Mestrado em Ciências Jurídicas) - Universidade Estadual do Norte do Paraná. 
LORENCINI, Marco Antonio Garcia Lopes. Prestação jurisdicional pelo Estado e meios alternativos de solução de controvérsias: convivência e formas de pacificação social. Tese (Doutorado) Universidade de São Paulo, São Paulo, 2006.

MENDES, Maria Lúcia R. de Castro P. Mediação e Conciliação. Histórico dos métodos adequados de solução de conflitos e experiências contemporâneas no Brasil e em outros países, in Estudos Avançados em Mediação e Arbitragem. São Paulo: Campos Elíseos. 2014.

MORAES, Márcio André Medeiros. Arbitragem nas relações de consumo. 1a ed. Curitiba: Juruá, 2005.

MUNIZ, Tânia Lobo. Arbitragem no Brasil e a Lei 9.307/96. Curitiba: Juruá. 1999.

RIBEIRO, Gustavo Pereira Leite. Arbitragem nas relações de Consumo. 1a ed. Curitiba: Juruá. 2006.

SALAMA, Bruno. A Economia da Arbitragem. In: Manual de Direito e Economia no Brasil. Luciano B. Timm (org.). São Paulo: Atlas, 2012.

SALES, Lilia Maia de Morais; SOUSA, Maria Almeida de. A Mediação e os ADR'S (Alternative Dispute resolutions) - A Experiência norte-americana. Revista Novos Estudos Jurídicos, vol. 19, n. 2, mai./ago. 2014.

SANDER, Frank. Future of ADR. Journal of Dispute Resolution, University of Missouri School of Law Scholarship Repositoryn, n. 1, article 5, 2000.

SOUZA, Salmo Caetano. A Natureza dos Bons Ofícios e da Mediação. Revista da Faculdade de Direito da Universidade de São Paulo, vol. 104, jan./dez. 2009.

SPENGLER, Fabiana Marion. Da Jurisdição à Mediação: Por um outra cultura no tratamento de conflitos. Ijuí: Editora Unijuí. 2010.

STRENGER, Irineu. Arbitragem Comercial Internacional. São Paulo: LTR, 1996.

VARELLA, Marcelo. Direito Internacional Público. 6a ed. São Paulo: Saraiva, 2016.

VASCONCELOS, Carlos Eduardo. Mediação de Conflitos e Práticas Restaurativas: Modelos, Processos, Ética e Aplicações. São Paulo: Método. 2008.

WAMBIER, Teresa Arruda Alvim. A Discussão sobre a disponibilidade do controle judicial da sentença arbitral e seus limites. Revista Brasileira de Arbitragem, n. 50, abr./jun. 2016.

WATANABE, Kazuo. Acesso à justiça e meios consensuais de solução de conflitos. In: Tribunal Multiportas - Investindo no capital social para maximizar o sistema de solução de conflitos no Brasil. (Org.) CRESPO, Maria Hernandez. Rio de Janeiro: FGV Editora, 2012. 
